\author{
Lecturer Gabriela GHEORGHIU, PhD \\ E-mail: gabriela.gheorghiu@365.univ-ovidius.ro \\ Professor Elena Cerasela SPĂTARIU, PhD \\ E-mail: elena.spatariu@365.univ-ovidius.ro \\ Lecturer Costin Octavian SORICI, PhD \\ E-mail: costin.sorici@365.univ-ovidius.ro \\ Faculty of Economic Sciences \\ "Ovidius" University of Constanta \\ Associate Professor Marcela ȘTEFAN, PhD \\ E-mail: marcela.stefan@eam.ase.ro \\ The Bucharest University of Economic Studies \\ Corina Larisa BUNGHEZ, PhD \\ E-mail: corina.bunghez@mk.ase.ro \\ The Bucharest University of Economic Studies
}

\title{
CREATING A SUSTAINABLE ENTREPRENEURIAL ECOSYSTEM AT HIGHER EDUCATION INSTITUTION LEVEL
}

\begin{abstract}
Creating a solid entrepreneurial ecosystem at national level is conditioned by the promotion of a strong culture of entrepreneurship. In Romania, however, creating such a system is a difficult mission due to the low level of entrepreneurial education that hinders the initiative in the field. In this context, the purpose of this study is to contribute to the understanding of the role that innovative universities can play in stimulating entrepreneurial initiative in a healthy business environment, as an engine of sustainable economic development. The example analyzed is the "Ovidius" University of the Constanta and its entrepreneurial transformation strategy, starting from an inclusive approach and a network perspective, which promotes entrepreneurship at all levels, facilitates interaction with other public and private actors from the community level, and supports the projects in the economic and social environment, all of them contributing to the creation of a sustainable entrepreneurial ecosystem at institution level.

Keywords: sustainable development, entrepreneurial ecosystem, university, education, entrepreneurship, innovation.
\end{abstract}

JEL Classification: I23, I25, M14

DOI: 10.24818/18423264/55.2.21.16 
Gabriela Gheorghiu, Costin Octavian Sorici, Elena Cerasela Spătariu, Marcela Ștefan, Corina Larisa Bunghez

\section{Introduction}

The role of entrepreneurship in the economy and society lies in the fact that it provides an opportunity for individuals and organizations to cope, provoke and perhaps even enjoy of an increasingly complex and uncertain world, in which sustainable development has become a necessity. Unfortunately, however, entrepreneurs do not step into this world with all the necessary competences, but their specific attitudes, knowledge and skills are developed over time in society and through education. That is why, investing in educational institutions in general, and especially those offering higher education, innovative and entrepreneurial, is one of the most important investments that can be made in modern society.

The conclusions of the research undertaken at the macro-economic level and synthesized in the specialized literature unequivocally point out that the creation of an entrepreneurial ecosystem is linked, among other things, to the use of human resources and the promotion of a strong culture of entrepreneurship. Starting from this consideration and in the context of Romanian entrepreneurial ecosystem's evaluation based on exploratory analysis carried out at national and international level, the present study underlines, in its first part, the need identified at national level to intensify efforts to support the entrepreneurial initiative as a driver of sustainable economic development. Further presented as a triggering and stimulating factor of the entrepreneurial initiative, the authors claim that the specialized education provided by the higher education institutions in Romania is still at a low level, the educational process quality and the provision of higher profile skills for graduates in their preparation for the labor market remaining one of the biggest challenges in efforts to stop and reverse the negative tendencies manifested in economic and social terms.

Despite the unfavorable institutional context, the authors underline in the second part of the study, the imperative of promoting innovation in higher education institutions, by stimulating, directly applying and exploiting knowledge for the benefit of the social, cultural and economic development of the society, which ensures the sustainability of the new entrepreneurial universities. In support of this idea, in the last part of the study are presented the solutions that the "Ovidius" University of Constanta implements since 2017 to create a sustainable entrepreneurial ecosystem meant to transform the institution into a regional pole of excellence in education, research and innovation, a true entrepreneurial university.

\section{Literature Review}

Entrepreneurship was initially approached in the literature as a promoter of innovation that contributes decisively to the development of sustainable products and services aimed at preserving the environment for future generations (Berle, 1991). Subsequently the link between entrepreneurship and sustainable

DOI: $10.24818 / 18423264 / 55.2 .21 .16$ 
Creating a Sustainable Entrepreneurial Ecosystem At Higher Education Institution Level

development was placed at the confluence of an enterprise's economic, social and environmental performances, meaning that, in order to be sustainable, an enterprise must ensure a threefold objective - to be economically viable, socially beneficial and environmentally responsible (Elkington, 1994).

A thorough analysis of the specialized literature under its time distribution report (Sarango-Lalangui, Santos and Hormiga, 2018) reveals that, although the debates on sustainable entrepreneurship have expanded only after 2006, showing an exponential growth in recent years, the diversity of definitions offered to describe this concept is not impressive (Hall, Daneke and Lenox, 2010). The central idea around which they revolve is aimed at balancing the economic, social and ecological outcomes that a sustainable entrepreneurial organization must embody by using available resources and capitalizing entrepreneurial opportunities (Hockerts and Wustenhagen, 2010).

In light of this idea and with regard to the current challenges of the globalized and dynamic business environment, entrepreneurial organizations must be skilled in handling innovation in order to preserve the sustainability of their activity. But innovation does not occur in a vacuum; it requires the openness and interaction between systems and their environmental environments, becoming a key long-term factor for economic development in general, and for sustainable development in particular.

The political motivations for innovation are, at least potentially, shared by all organizations, whether private or public, although by their nature they are less susceptible to rational planning and analysis (Mintzberg, 1989). In contrast, the economic and strategic motivations are mainly applicable, at least at first glance, to private organizations, because public ones do not tend to act in the context of competitive markets, but they usually exist within a more complex social system, with goals and values that are more ambiguous and difficult to quantify (Marsh and Olsen, 1989). Despite the fact that, for the latter, the incentives for innovation are lower, and the risks are often higher than in the private sector (Kamarck, 2004), in the specialized literature it is emphasized that there are important arguments to extend the innovation imperative from private to public organizations, in order to guarantee the maximization of government investment's value, with considerable benefits on social welfare (Lekhi, 2011).

The education sector is no exception. Traditionally appreciated by experts as a non-productive sector (Baumol and Bowen, 1965), in education innovation can add a real value to this public service, which must also adapt to the needs of a changing economy and society. However, most of the times, in education the changes are proposed outside the public organizations working in the field (schools, universities, training centers etc.), after which they are disseminated within them, the source of these changes being not innovation, but the national reform of the education system triggered by government actors (Foray and Raffo, 2012).

DOI: 10.24818/18423264/55.2.21.16 
Gabriela Gheorghiu, Costin Octavian Sorici, Elena Cerasela Spătariu, Marcela Ștefan, Corina Larisa Bunghez

A particular attention is paid in the specialized literature to tertiary education institutions, respectively to universities, and to the conditions in which they can be considered as innovative. (Gibbons et al, 1994; Clark, 1998)

The definitions of "innovative university" start from the idea that the world is changing rapidly, and universities must adapt to these changes as well. (Trow, 1996; Kennedy, 1997) If universities' traditional mission has been recognized as that of preserving and disseminating knowledge through the process of teaching and learning, it was extended further to enclose research mission, so that lately participation in economic and social development to become an integral part of universities' mission, by supporting the transfer of technology. (Van Vught, 1999)

In the context of these new tendencies, a new concept has emerged in the specialized literature, which derives from that of "innovative university", namely "entrepreneurial university". Since its introduction into the literature almost four decades ago (Etzkowitz, 1983), it has experienced a variety of inventive, creative and even practical approaches, without so far reaching a unanimously accepted definition. However, similarities can be identified regarding certain characteristics attributed to the entrepreneurial university, related to: the partnership relationship developed with governments and companies; diversified sources of income; the entrepreneurial activities of all community members (faculties, employees, students); implementation of different strategies for new projects development and for organizational structure adjustments (Guerrero, Urbano and Kirby, 2006).

Based on these characteristics, the European Commission has developed in collaboration with the Organization for Economic Cooperation and Development (2012) a general guiding framework to serve higher education institutions wishing to explore their innovative potential through a self-assessment aimed at identifying strengths versus weaknesses and potential ways of action to become sustainable entrepreneurial organizations, in the context of the local and national environment in which they operate. This general framework is based on the HEInnovate tool, which enables governmental and higher education institutions to identify priority areas of action for creating an innovative and sustainable entrepreneurial ecosystem.

\section{Research Methodology}

The present scientific research approach starts from the evaluation of the Romanian entrepreneurial ecosystem with the help of the indicators considered determinants for the entrepreneurial activity development and calculated from the exploratory analysis undertaken at the national level by the Executive Unit for the Financing of Higher Education, Research, Development and Innovation (Romanian entrepreneurial ecosystem Index, 2015), and internationally by the Global Entrepreneurship Monitor (National entrepreneurial framework conditions Index, 2015) and the World Bank Group (Ease of doing business Index, 2019).

DOI: $10.24818 / 18423264 / 55.2 .21 .16$ 
Creating a Sustainable Entrepreneurial Ecosystem At Higher Education Institution Level

Further, by interpreting the statistical information provided by Eurostat and the European Commission' specialized studies (2019), is presented the national entrepreneurial context in which the institutions of tertiary education operate. The analysis is after that elaborated with the help of the HEInnovate tool developed by the European Commission in collaboration with the Organization for Economic Cooperation and Development and which is built around seven areas of interest covering the vast majority of the features considered to be common to entrepreneurial universities within the existing definitions regarding this concept, namely: leadership and governance; organizational capacity, people and incentives; entrepreneurial teaching and learning; preparing and supporting entrepreneurs; knowledge exchange and collaboration; the internationalized institution; measuring impact.

Appreciated as a self-assessment tool, HEInnovate consists of an opinion poll applied to the Romanian universities during the period 2016-2017, with the help of Junior Achievement Romania, and involves completing an online questionnaire containing thematic statements grouped on the aforementioned areas of interest and addressed to the higher education institution' stakeholders. Each statement / situation is scored by the respondents with scores from 1 to 5 (N / A not applicable, 1 is the lowest score and 5 is the highest score).

The same tool is used by the authors to characterize the "Ovidius" University of Constanța entrepreneurial context and to underline the strengths and weaknesses that continued to serve as a starting point in presenting the strategy developed by the higher education institution to create a sustainable entrepreneurial ecosystem.

\section{Evaluation of the Romanian entrepreneurial ecosystem}

Exploratory analysis of the national entrepreneurial ecosystem undertaken in 2015 from the perspective of the relationships established between various determinants of economic development, such as leadership, human capital or culture, and which also influence entrepreneurship to the extent that finance and markets do, highlighted that this ecosystem is very poorly developed in Romania, as the links established between the entrepreneurs are not strong enough to lead to an self-sustaining environment. The Romanian entrepreneurial ecosystem Index is valued at 4.5 on a scale from 0 to 10 attributed by the entrepreneurs in the evaluation of five dimensions appreciated as determinants for the development of a healthy entrepreneurial ecosystem, namely: inspiration, consultancy, work experience, mentoring and investments, each of these dimensions being measured on a scale from 0 to 2 with the help of an online survey attended by Romanian entrepreneurs. (Executive Unit for Financing Higher Education, Research, Development and Innovation, 2015)

The results of the exploratory analysis undertaken at the national level can be combined with the comparative analysis performed also at international level in

DOI: 10.24818/18423264/55.2.21.16 
Gabriela Gheorghiu, Costin Octavian Sorici, Elena Cerasela Spătariu, Marcela Ștefan, Corina Larisa Bunghez

2015 , which reveals, on a scale from 1 to 5 assigned by experts in the evaluation of 12 dimensions appreciated as determinants for the assessment of the national entrepreneurial framework, the fact that the performances registered at the national level are low (the average score reported for all 12 dimensions is 2.4), the weaknesses of the Romanian entrepreneurial ecosystem being related to the reduced access to the necessary resources for financing this activity and the insufficient and inefficient government policies for supporting entrepreneurship. (Global Entrepreneurship Monitor, 2015) (Figure no. 1)

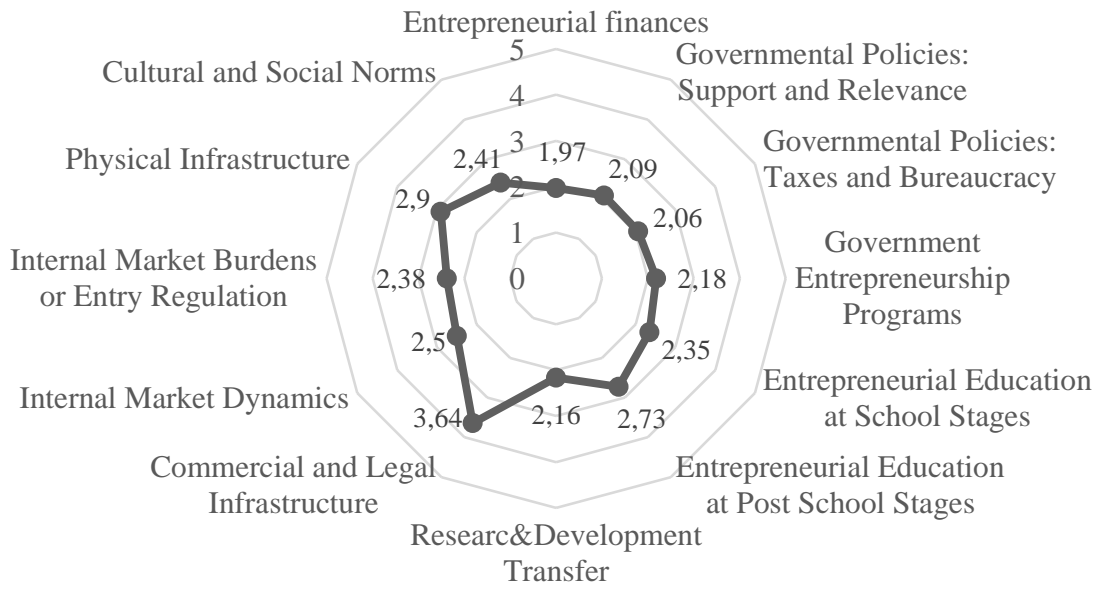

Figure 1: National entrepreneurial framework conditions

Source: Global Entrepreneurship Monitor, 2015

https://www.gemconsortium.org/economy-profiles/romania

Among the dimensions to which the analysis in question refers, the ones concerning the entrepreneurial education are noted, which confirms its importance for the sustainability of the national entrepreneurial ecosystem. Moreover, the analysis highlights that the entrepreneurial activity's intensity is inextricably linked to the education level (with emphasis on the entrepreneurial one), the first becoming higher as long as the education level is higher, this interdependence relationship proving to be stable not only in time, but also among the analysed national economies, regardless of their level of development. Also, the studies in this field unequivocally confirm the favourable impact that entrepreneurship education has on the entrepreneurial mentality of young people, on their entrepreneurial intentions and their role in society and in the economy (European Commission, 2012)

However, the national institutional context does not create a favourable framework for encouraging entrepreneurial attitudes, a situation which has worsened in recent years, with significant negative effects on business

DOI: 10.24818/18423264/55.2.21.16 
Creating a Sustainable Entrepreneurial Ecosystem At Higher Education Institution Level

development. Thus, Romania is experiencing a constant involution from this point of view, our country being ranked 55th (in 2019) out of 190 countries taken into account in calculating the Ease of doing business Index, comparing with 36th in 2016. (World Bank Group, 2019)

Given this nationally portrayed picture, entrepreneurship education becomes the vehicle that can really contribute to improving the situation, innovating and not just reforming the education system in general, and the higher education system in particular, should become a priority in order to stop and reverse these negative tendencies.

\section{Sustainable entrepreneurship in higher education institutions - national context}

Public expenditures for education are in Romania at a low level (2.8\% of GDP in 2017), our country recording the lowest performance in the European Union (whose average is 4.6\%), although the financing needs of the sector are enormous, in order to improve the quality of the human resource available on the labour market, which will contribute further to the economic development. (European Commission, 2019) Most financial resources are directed to secondary education (42.8\% of total public expenditure for education in 2017), followed by primary and tertiary education $(21.4 \%$ each).

In addition to the declining public spending in the tertiary education sector ( $0.6 \%$ in 2017 compared to $1.3 \%$ in 2008 as a percentage of GDP), participation in higher education is still low. Thus, in 2018, the level of tertiary education graduation for the age group 30-34 years decreased to $24.6 \%$ from $26.3 \%$ in 2017, lower than the European Union average of $40.7 \%$, and even lower than Romania's national target of $26.7 \%$ assumed under the Europe 2020 Strategy, given that gross enrolment rates have not only remained low, but have steadily declined since 2009 and so far (Commission European, 2019). Among the factors leading to this discouraging evolution are the demographic ones, the school dropout from early ages, as well as the high percentage of failure to pass the baccalaureate exam.

In this context, the educational process' quality and the provision of increased skills for graduates in their preparation for the labour market, remains one of the biggest challenges. Moreover, despite the high percentage of young graduates of tertiary education who are hired at the end of their studies $(89 \%$ in 2018 compared to the EU average of 85.5\%), employers report that the knowledge bag they hold is predominantly theoretical, and less practical. So, the collaboration between the academic and business environment becomes very important, starting from the mutual consultations on the university curriculum construction, to the development of joint projects meant to increase the attractiveness of the study programs and their adaptability to the employers' demands. This is where the premises of increasing the complexity of the universities' activity are created by developing their third mission, complemented by the traditional ones of education

DOI: 10.24818/18423264/55.2.21.16 
Gabriela Gheorghiu, Costin Octavian Sorici, Elena Cerasela Spătariu, Marcela Ștefan, Corina Larisa Bunghez

and research, which consists mainly in the stimulation, direct application and exploitation of knowledge for the benefit of society's economic, social and cultural development - which ensures the activity's sustainability of real entrepreneurial universities.

Application of the HEInnovate tool to the Romanian universities between 2016 and 2017, with the support and through the activities promoted by Junior Achievement Romania, concludes that in the national higher education institutions the entrepreneurial education is found more as a study object within the economics and business faculties, presenting a pronounced theoretical character, and less applicative or oriented to the market needs, because the involvement of business environment representatives in the development process of disciplines' content and university study programs' structure is generally low. (Organization for Economic Cooperation and Development / European Commission, 2019)

However, the national assessment of the entrepreneurial education level is not limited only to the study programs' content, the way in which it is delivered or to the number of students enrolled in the profile programs. It should also include how entrepreneurship education relates to lifelong competences, and how it contributes to improving the life quality by developing the human and social capital needed to promote knowledge exchange and collaboration with relevant actors, and to ensure the entrepreneurial ecosystem's sustainability at all levels local, regional, national and international.

\section{Entrepreneurial context at "Ovidius" University of Constanta}

The "Ovidius" University of Constanta (OUC) is a public higher education institution established in 1961 and became in 1990 a multidisciplinary multicultural university, with national and international accredited study programs in very diverse fields of human knowledge. With nearly 15,000 students in bachelor's, master's, residency and doctoral programs and over 1,000 teaching and administrative staff, OUC is the largest university in the European Union at the Black Sea.

Ranked in the international hierarchy of QS Top Universities among the top 12 universities in Romania (out of 17 selected from the nearly 100) and in the first 250 institutions of higher education in emerging countries from Europe and Central Asia, the OUC is dedicated to creating, treasuring and transmitting knowledge to society, through education, scientific research and artistic creation, at European quality standards, strongly involved in solving regional problems and in the Black Sea basin. In this regard, the OUC has carried out over the last several years many projects financed from European funds, including through the Regional Operational Program, by which it contributed, on the one hand, to the implementation of solutions that help both private companies and local public authorities or other public institutions to carry out their activity effectively and to respond to the challenges arising from their internal and external environment, and 
Creating a Sustainable Entrepreneurial Ecosystem At Higher Education Institution Level

on the other hand, to the socio-economic development of the Constanta city and county and of the entire $2^{\text {nd }}$ South-East Region. All these actions create the premise of developing a sustainable entrepreneurial ecosystem at higher education institution level.

The need as such was confirmed by the diagnostic analysis undertaken with the help of HEInnovate self-assessment carried out online during 2016-2017 period, attended by 476 people, representing three general groups within the institution and, where appropriate, external partners, respectively: students, nonstudents (respectively teachers, management representatives at the faculty and university level, experts-researchers, administrative staff, external partners, etc.) and anonymous persons. This self-assessment evaluates the opinion of the University's stakeholders regarding seven main characteristics considered defining for an entrepreneurial higher education institution.

In this context, it is revealed as the institution's strength its degree of activities' internationalization (Figure no. 2) reflected by explicitly support of the employees and students' international mobility, especially within the Erasmus Plus program, but also by the increasing number of foreign students accessing the study programs included in the educational offer of the faculties in the OUC organizational structure.

The institution's weakness is preparing and supporting entrepreneurs' activity (also Figure no. 2), available only in the framework of economic studies programs, where there are dedicated disciplines, as well as a mandatory specialty internship that facilitates the practical knowledge's transfer to the subjects of learning.

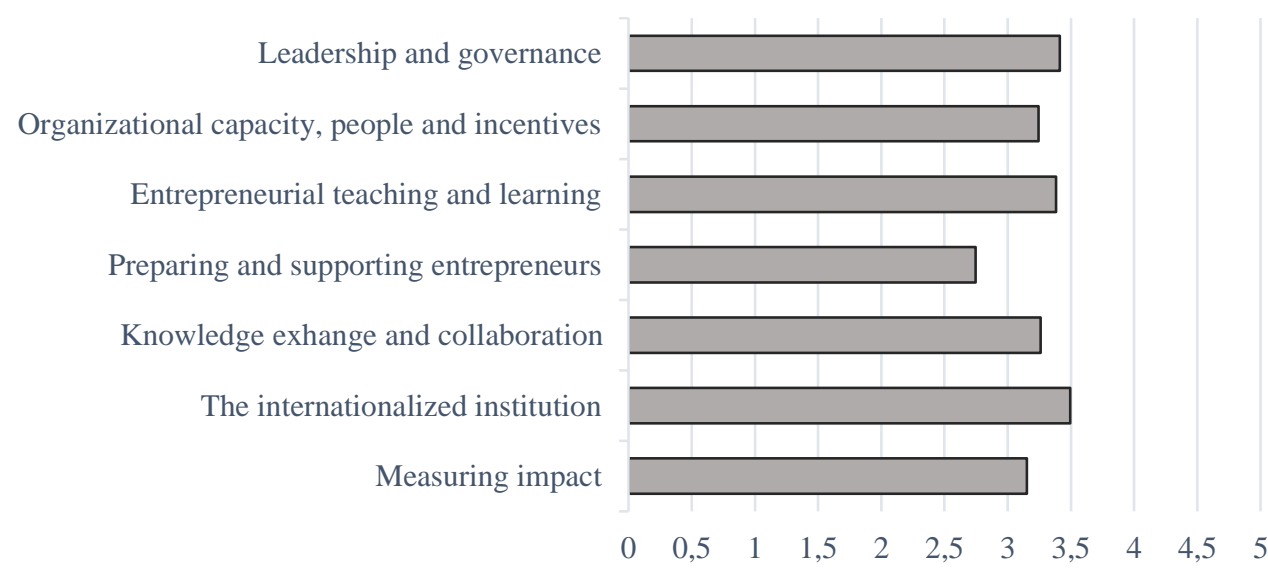

Figure 2: The results of the HEInnovate self-assessment at OUC

(average number of responses provided for each pillar, number of respondents $=476$ )

DOI: 10.24818/18423264/55.2.21.16 
Gabriela Gheorghiu, Costin Octavian Sorici, Elena Cerasela Spătariu, Marcela Ștefan, Corina Larisa Bunghez

Given this weakness revealed following the application of the HEI selfassessment tool, we aimed to identify which of the other six characteristics of an entrepreneurial university highlighted above can contribute to a positive assessment from institution's stakeholders in this regard. To this end, we used the Data Analysis package available in the Microsoft Excel application to calculate the value of the Pearson coefficient in order to identify a possible correlation between these characteristics. The values calculated using the mentioned application indicated as the most significant possible correlation (Pearson coefficient $=$ 0.842470309) between the assessment of the characteristic related to preparing and supporting entrepreneurs and the one aimed at measuring the impact of entrepreneurial changes made within the institution (Table 1).

\section{Table 1: Pearson coefficient test of the correlation between entrepreneurial characteristics}

\begin{tabular}{|l|c|}
\hline $\begin{array}{c}\text { Correlation between Preparing and supporting entrepreneurs } \\
\text { characteristic and the other entrepreneurial dimensions }\end{array}$ & $\begin{array}{c}\text { Pearson } \\
\text { coefficient }\end{array}$ \\
\hline Leadership and governance & 0.70971594 \\
\hline Organizational capacity, people and incentives & 0.727910219 \\
\hline Entrepreneurial teaching and learning & 0.796255614 \\
\hline Knowledge exchange and collaboration & 0.706642797 \\
\hline The internationalized institution & 0.730530635 \\
\hline Measuring impact & 0.842470309 \\
\hline
\end{tabular}

Source: calculation made by the authors using the Data Analysis package from the Microsoft Excel application

Further, by applying the Regression function available within the same Data Analysis package, the calculation resulted in a correlation coefficient of 0.83 , respectively a determination coefficient of 0.69 between the two characteristics, with significant $\mathrm{F}$ and $\mathrm{P}$ values (Table no. 2). We could therefore deduce from these results that the variation $(69 \%)$ of the dependent variable related to the preparing and supporting entrepreneurs can be influenced by changes produced in the independent variable related to the measuring the impact of entrepreneurial changes made within the institution.

Table 2: Summary output for the regression test of the correlation between entrepreneurial characteristics

\begin{tabular}{lr}
\hline \multicolumn{2}{c}{ Regression Statistics } \\
\hline Multiple R & 0,831160935 \\
R Square & 0,6908285 \\
Adjusted R Square & 0,69017486 \\
Standard Error & 0,675120746 \\
Observations & 475 \\
\hline
\end{tabular}

DOI: $10.24818 / 18423264 / 55.2 .21 .16$ 
Creating a Sustainable Entrepreneurial Ecosystem At Higher Education Institution Level

\begin{tabular}{|c|c|c|c|c|c|}
\hline \multicolumn{6}{|l|}{ ANOVA } \\
\hline & $d f$ & $S S$ & $M S$ & $F$ & Significance $F$ \\
\hline Regression & 1 & 481,720181 & 481,72018 & 1056,8952 & $1,1922 \mathrm{E}-122$ \\
\hline Residual & 473 & 215,587735 & 0,455788 & & \\
\hline Total & 474 & \multicolumn{2}{|l|}{697,307916} & & \\
\hline & \multicolumn{2}{|c|}{ Coefficients } & adard Error & $t$ Stat & $P$-value \\
\hline Intercept & \multicolumn{2}{|c|}{1,078026432} & 0,07662367 & 14,069104 & $8,341 \mathrm{E}-38$ \\
\hline Measuring impact & \multicolumn{2}{|c|}{0,75223288} & 0,02313856 & 32,509925 & $1,19 \mathrm{E}-122$ \\
\hline & \multicolumn{2}{|c|}{ Lower 95\% } & Upper 95\% & Lower 95,0\% & Upper 95,0\% \\
\hline & \multicolumn{2}{|c|}{0,927461527} & 1,228591 & 0,9274615 & 1,228591 \\
\hline & \multicolumn{2}{|c|}{0,706765793} & 0,7977 & 0,7067658 & 0,7977 \\
\hline
\end{tabular}

Source: calculation made by the authors using the Data Analysis package from the

Microsoft Excel application

The concept of entrepreneurial higher education institution combines the perception that the institution has about itself, the reflection on what is happening outside and the approach based on concrete evidence. However, the impact on higher education institutions is not properly measured even at "Ovidius" University level. Current measures usually focus on the number of spinoffs (new entities or organizations, formed by detachment from a larger one), the volume and quality of the generation of intellectual property and research revenue, not necessarily how many graduates have become entrepreneurs, on the results of the teaching and learning process, on the retention of talented employees, on the contribution to the local economic development or on the impact of the entrepreneurial program as a whole.

\section{The approach of "Ovidius" University of Constanta in creating a sustainable entrepreneurial ecosystem}

Starting from results of the diagnostic analysis and taking into account the institutional context, the OUC management took on the strategic concept and the action plan for transforming the institution into a sustainable entrepreneurial university

The chosen strategic concept offers a comprehensive approach to entrepreneurship and innovation, capable of ensuring a sustainable ecosystem. The OUC's vision in this specific field, for the period 2017-2022, aims at transforming the institution into a regional hub for entrepreneurship and innovation, capable of coagulating and channeling the efforts and resources in this area not only in the South- Eastern region of Romania but in the entire Black Sea basin.

In order to support this vision, the OUC strategic concept of entrepreneurial university is based on three main vertical pillars: entrepreneurship

DOI: $10.24818 / 18423264 / 55.2 .21 .16$ 
Gabriela Gheorghiu, Costin Octavian Sorici, Elena Cerasela Spătariu, Marcela Ștefan, Corina Larisa Bunghez

in education, entrepreneurship in research-innovation and community involvement (social entrepreneurship), the three directions complementing and working together in synergy. For each of these three pillars the base is provided by three critical sources: the people involved, the supportive infrastructure and the necessary money. For each of these three verticals a set of specific operational objectives has been defined, while the transversal elements represent the means of implementation but also the main challenges of the implementation team.

Thus, in the education pillar, the main operational objectives aim at: business community's involvement in designing courses and programs that will consider the development of the entrepreneurial knowledge, skills and competences (soft-skills); the introduction of mixed entrepreneurship programs for students from all specializations in the university; the introduction of training programs for teachers about innovative teaching methods (project-based learning, blendedlearning, experiential learning); the introduction of business plan competitions and business models for students from all study programs; the creation of preacceleration, acceleration and lock-up programs for innovative ideas.

In the research-innovation pillar, the objectives aim at: the support for the research and innovation partnership with the private environment; the support for research and innovation initiatives with multi-disciplinary and trans-disciplinary groups; the creation of technological tools and infrastructure; encouraging the emergence and financial support of start-ups and spin-offs.

In the community involvement pillar, the main objective is to position the university as an active player in community, an initiator and supporter of the social, cultural and community development projects. In this regard, the university is a founding member of important regional clusters, which covers most of the areas of interest from regional intelligent development strategies and is an active member of national and European research-innovation-entrepreneurship networks at national and European level.

In each of these three directions, programs and projects with governmental support were implemented or are ongoing for the last three years with European funds or with public or private money at the local community level.

In implementing its strategy on people, OUC has created a dual hierarchical structure, adding to the traditional hierarchy an Entrepreneurship Center (Ovidius Innovation Center), which has a role in initiating and coordinating innovation and entrepreneurship projects for both students and teaching and research staff, in order to attract as many as possible from the about 700 teachers, researchers and auxiliary staff of the university, of which only a nucleus of 20 initially embraced, without reservation, the proposed action plan. The Entrepreneurship Center team put into practice the eight accelerators of change in an organization and managed to triple the number of people in the actual ownership area (Kotter, 2019).

The second challenge in terms of implementing the strategy was the creation of the necessary innovation and entrepreneurship infrastructure. Thus,

DOI: 10.24818/18423264/55.2.21.16 
Creating a Sustainable Entrepreneurial Ecosystem At Higher Education Institution Level

besides the position occupied by the Entrepreneurship Center in the organizational chart, other structures have been created to support the area of innovation and entrepreneurship, namely: a Digital Innovation HUB (created with the help of an European project); an Innovation and Technological Transfer Center (Ovidius Innovation Hub); as well as a Student Hub (Google Digital Workshop). These three structures, subordinated to the university's Research-Innovation Department, are designed to collaborate with the Entrepreneurship Center and jointly support all initiatives in the field of innovation and entrepreneurship not only from the university, but also from the local community and other consortia where the university is engaged. The four structures together managed to initiate and implement over 15 innovation and entrepreneurship projects during 2017-2019 period in all three directions and six levels of ecosystem manifestation.

Although important, the third transversal component of the matrix money, was easier to overcome in the context where, with the support of European funds, the funds received from the Romanian Government, own funds or the ones attracted from local public and private partners, it has been possible to build the logistical and contextual foundations that now allow the acceleration of ecosystem development. The partnerships developed with Junior Achievement Romania, Romanian-American Foundation, Google Romania, the co-founding of the Association for Entrepreneurial Education by alumni teachers of the RAFFulbright program from ten Romanian universities, contributed to the successful start and consolidation of Constanta's ecosystem.

The period 2020-2022 will be for strengthening the approach in the strategic concept of innovation and entrepreneurship and making it an irreversible trend at university level. In addition to recurring initiatives and projects, the annual strategic action plan for the following years will focus on: the construction of a building to house the Innovation and Technology Transfer Center and a business incubator for companies created by students and graduates; the introduction of a mentoring program and access to the financing for the start-up and spin-off created; the development of a local network of angel-investors; the creation of a fundraising and community involvement center at university level and a strong alumni network; the establishment of new innovative clusters.

\section{Conclusions}

The diagnostic analysis implemented at „Ovidius" University of Constanta's level between 2016 and 2017, with the help of the HEInnovate selfassessment tool, confirmed that universities form an important part and resource for the local business community. The flux of talented and well-prepared youth is the first valuable component which a university brings to an entrepreneurial ecosystem. Some students will be interested in becoming entrepreneurs, while a larger number of students will wish to work for the entrepreneurial companies and

DOI: 10.24818/18423264/55.2.21.16 
Gabriela Gheorghiu, Costin Octavian Sorici, Elena Cerasela Spătariu, Marcela Ștefan, Corina Larisa Bunghez

organizations from the local economic and social environment. In either situation the efficient connection of the local business community and the students brings a huge benefit to all parties involved.

The research-innovation potential which could be transferred is the second valuable component which the university could bring to the local community. The universities' research institutions and collectives provide valuable products to the fundamental or applicative research zone which can easily be transformed into patents and licenses. Then they could be transferred towards the local community as market products and services. The essential condition in this case is the existence of mechanisms to encourage interdisciplinary and trans-disciplinary collaboration as well as an infrastructure to facilitate and support technology transfer.

In this context, the strategic concept of transforming "Ovidius" University of Constanta into an entrepreneurial university is an ambitious endeavor, which has required an effort of analysis, documentation, design and an especially important implementation during the last 3 years.

The full implementation of the strategy will give the university the role of regional hub for innovation and entrepreneurship and will generate multiple beneficial advantages for the local community and business environment. The main role of the university in a sustainable local entrepreneurial ecosystem is of key resource, talent provider and connector of valuable ideas and expertise. It is therefore extremely beneficial for those implementing the entrepreneurial transformation strategy to have an inclusive approach and network perspective, facilitating interaction with other public and private actors at the community level and supporting projects in the economic and social environment.

A major concern for the next period is the definition of a set of key indicators for measuring the performance of innovation and entrepreneurship activity in the university entrepreneurial ecosystem, as well as introducing ways to motivate, recognize and reward the efforts of the performers in the system, corresponding with the needs and directions to follow from the strategic concept.

\section{REFERENCES}

[1] Baumol, W.J., Bowen, W.G. (1965), On the Performing Arts: The Anatomy of their Economic Problems. American Economic Review, 55(1/2): 495-502;

[2] Berle, G. (1991), The Green Entrepreneur: Business Opportunities that Can Save the Earth and Make You Money. Blue Ridge Summit Pennsylvania: Liberty Hall Press;

[3] Elkington, J. (1994), Towards the Sustainable Corporation: Win-Win-Win Business Strategies for Sustainable Development. California Management Review, 36(2): 90-100; 
Creating a Sustainable Entrepreneurial Ecosystem At Higher Education Institution Level

[4] Etzkowitz, H. (1983), Entrepreneurial Scientists and Entrepreneurial Universities in American Academic Science. Minerva, 21(2-3): 198-233;

[5] European Commission, DG Enterprise and Industry (2012), Effects and Impact of Entrepreneurship Programmes in Higher Education. Bruxelles;

[6] European Commission (2019), Education and Training Monitor 2019.

Luxembourg: Publications Office of the European Union;

[7] Executive Unit for Financing Higher Education, Research, Development and Innovation (2015), The Romanian Entrepreneurial Ecosystem, an Exploratory Study. Bucharest: Prospective Press;

[8] Foray, D., Raffo, J. (2012), Business-driven Innovation: Is it Making a Difference in Education? An Analysis of Educational Patents. OECD Education Working Papers No. 84, Paris: OECD Publishing ;

[9] Gibbons M. et al. (1994), The New Production of Knowledge, The Dynamics of Science and Research in Contemporary Societies. London: Sage; [10] Global Entrepreneurship Monitor (2017), Global Entrepreneurship Monitor. Entrepreneurship in Romania. [online] Available at: https://www.gemconsortium.org/economy-profiles/romania [17 March 2020]; [11] Guerrero, M., Urbano, D., Kirby, D.A. (2006), A Literature Review on Entrepreneurial Universities: An Institutional Approach. Working paper presented at the 3rd Conference of Pre-communications to Congresses. Business Economic Department. Autonomous University of Barcelona. Barcelona; [12] Hall, J., Daneke, G., Lenox, M. (2010), Sustainable Development and Entrepreneurship: Past Contributions and Future, Directions. Journal of Business Venturing, 25(5): 439-448;

[13] Hockerts, K., Wüstenhagen, R. (2010), Greening Goliaths versus Emerging Davids: Theorizing about the Role of Incumbents and New Entrants in Sustainable Entrepreneurship. Journal of Business Venturing, 25(5): 481-492; [14] Junior Achievement Romania (2018), The General Results of the “Ovidius" University of Constanta Participation in the HEI Innovate SelfAssessment - internal document; [15] Kamarck, E.C. (2004), Government Innovation around the World. Ash Institute for Democratic Governance and Innovation, John F. Kennedy School of Government, Harvard University. [online] Available at: https://www.innovations.harvard.edu/sites/default/files/2551.pdf [Accessed 17 March 2020];

[16] Kennedy, D. (1997), Academic Duty. Cambridge, MA: Harvard University Press;

[17] Kotter, J. P. (2014), Accelerate: Building Strategic Agility for a FasterMoving World. Boston: Harvard Business Review Press;

[18] Lekhi, R. (2011), Innovation, Public Policy and Public Services Delivery in the UK. The Word that Would Be King? Public Administration, 89(4): 1335 1350 ;

DOI: $10.24818 / 18423264 / 55.2 .21 .16$ 
Gabriela Gheorghiu, Costin Octavian Sorici, Elena Cerasela Spătariu, Marcela Ștefan, Corina Larisa Bunghez

[19] Marsh, J.G., Olsen, J.P. (1989), Rediscovering Institutions: The Organizational Basis of Politics. New York: Free Press;

[20] Mintzberg, H. (1989), Mintzberg on Management: Inside our Strange

World of Organizations. New York: Free Press;

[21] Organizaton for Economic Cooperation and Development / European

Commission (2012), A Guiding Framework for Entrepreneurial Universities.

Paris: OECD Publishing;

[22] Organizaton for Economic Cooperation and Development / European

Commission (2019), Supporting Entrepreneurship and Innovation in Higher

Education in Romania. Paris: OECD Publishing;

[23] „Ovidius” University of Constanta (2016), Strategic Plan for 2016-2020.

[online] Available at: http://www.univ-

ovidius.ro/images/docs/regulamente/v6/Plan\%20strategic\%20UOC.pdf [24 May

2020];

[24] Sarango-Lalangui, P., Santos, J.L.S., Hormiga, E. (2018), The

Development of Sustainable Entrepreneurship Research Field. Sustainability,

10(6): 1-19;

[25] Trow, M.T. (1996), Markets and Accountability in Higher Education, a

Comparative Perspective. Higher Education Policy, 9(4): 309-324;

[26] Tushman, M.L., O'Reilly, C.A. (1996), Ambidextrous Organizations:

Managing Evolutionary and Revolutionary Change. California Management Review, 38(4): 8-30;

[27] Van Vught, F. (1999), Innovative Universities. Tertiary Education and

Management, 5(4): 347-354;

[28] World Bank Group (2019), Doing Business 2020. Economy Profile

Romania. [online] Available at:

https://www.doingbusiness.org/content/dam/doingBusiness/country/r/romania/RO

M.pdf [24 May 2020]

DOI: 10.24818/18423264/55.2.21.16 